\title{
The Quantitative and Qualitative Analysis of Organizational Citizenship Behavior
}

\author{
Bülent G̈̈VEN
}

\begin{abstract}
Organizational citizenship behavior is voluntarily behavior. Even though it is not mandatory, it contributes to business goals and objectives which are important issues for organizations. The present study aims to determine organizational citizenship behavior and its dimensions with a detailed literature. The overall objective is to describe organizational citizenship behavior and its dimensions through the qualitative and quantitative research conducted on employees of a textile company in Adlyaman, Turkey. The study will begin with the qualitative research focus on the company's organizational citizenship behavior by using Schein's joint exploration method through iterative interviewing. The second part of research will be the quantitative section, which will study the company using the method of survey and will draw together the findings and present alternative evaluations.
\end{abstract}

Keywords: Organizational Citizenship Behavior, Paradigm, Altruism, Conscientiousness, Courtesy, Sportsmanship, Civil Virtue.

\section{Introduction}

For organizations, the most expected and desirable type of behavior from its members is to present a self sacrificing role that does not require motivations such as sanctions, incentive propaganda, or any type of mandatory enforcement. Today, organizations expect their members to demonstrate behaviours that are not enforced, but behaviors that have a positive contribution to organizaton in addition to their formal duties to achieve their goals and objectives.

Behaviors that are not included in the employee' s job description, but whose importance in organizational motivation and success are vital, are conceptualized as organizational citizenship behavior (Gürbüz, 2006: 57). In other words, organizational citizenship behavior is a concept that expresses the voluntary behavior of employees in order to contribute, beyond their formal tasks and expectations (Karaman and Aylan, 2012: 36). At the same time, organizational citizenship behavior (OCB), which is a demonstration of personal responsibility, helps the organization to achieve its targeted purposes and desires. Van Dyne, Cummings, and McLean (1995) argued that the goal of organizational citizenship behavior(OCB) should serve the goals and objectives of the organization and claimed that for certain behavior to be regarded in the context of organizational citizenship behavior, it should be welcomed positively by a person outside the organization (Arslantaş and Pekdemir, 2007: 265). In this context OCB appears as one of the important factors for the organization. Organizational citizenship behavior (OCB) includes behavior and attitudes based on non-mandatory or voluntary actions of the members. Those voluntary behaviors are influenced by certain factors. An increase in the display of organizational citizenship behavior provides important benefits to reach the aims and objectives of the organizations. As a result of the OCB behavior, companies or organizations are likely to provide a nurturing atmosphere and support for the employees and in return organizations will receive benefits such as increased employees' performance, job satisfaction, organizational commitment and organizational justice.

The main purpose of this research is to provide a qualitative and quantitative research on Organizational Citizenship Behavior (OMC), its dimensions and to provide a different perspective on organizational citizenship behaviors and its dimensions. The first part of the study consists of the literature study on organizational citizenship behaviors and its dimensions while the second part is consisted of qualitative and quantitative analysis of the results. The definition, characteristics and dimensions of organizational leadership behavior in the conceptual framework will be presented. In the first part of the research application section, a qualitative research example will be presented by using paradigms developed on organizational citizenship behavior, and Schein's "the Joint Exploration through Iterative Interviewing method" will be used for organizational culture analysis. 
In the second part of the research, through a quantitative research, the level of organizational citizenship behavior and its dimensions on employees will be examined by analyzing OCB and its dimensions through an empirical study conducted on employees. I will also try to explain whether there is a difference in terms of exhibiting and internalizing organizational citizenship behaviors and its dimensions among employees with different levels of education, work experience and age groups. In the conclusion section, qualitative and quantitative research results obtained about organizational citizenship behaviors, its dimensions, and suggestions for futher studies will be presented.

\section{The Concept of Organizational Citizenship Behavior}

Due to excessive competition, market shrinkages and difficulties experienced in the business world, the uncertainities in the global and national economies have caused the firms to shrink and establish team - based organizations. Accordingly, efficent and more reliable employees in the enterprises are in demand; therefore, organizational citizenship behavior has become more significant (Gürbüz, 2006: 51).In terms of allegiance to the organization, volunteer behavior, the principles of organizational citizenship behavior are taken up by employees such behaviors are not formally defined by the members of the organization. The concept was mentioned for the first time by Chester Bernard in 1930s (Danaeefard et al., 2010: 148).

Organizational citizenship behavior has been defined by Bateman and Organ (1983) as "good soldier syndrome"; George (1991) defined the term as "prosocial behavior"; while George and Brief (1992) defined it as "spontaneous behavior" (Gürbüz, 2006: 50-51). Goodman and Svyantek (1999) have described OCB as "contextual performance" while Finkelstein and Penner (2004) as "social organization behavior" (Sezgin, 2005: 319). George and Jones (1997: 155) termed the concept of organizational citizenship behavior as organizational volunteering (or willingness). Brief and Motowidlo (1986: 710), on the other hand, describe term as as prosocial behavior; and define it as the totality of the activities, an employee performs both for his/herown and the company wellbeing that he or she works for.

According to Organ and Konovsky (1989), the OCB is a behavior that positively affects the image and reputation of the organizaton, which facilitates co-operation and intra-company cohesion, and is categorically defined as "spontaneous behavior" (Aslan, 2008: 166). The factor that shaped organizational citizenship behavior, is also referred as "extra-role behavior" by Katz and Kahn (978: 76). It is voluntary activity without any guilt anxiety or reward expectation and it is complimentary to employee' s duties. In this extra-role behavior, the employee is more committed than expected (Greenberg and Baron, 2000: 212).

Organ (1988: 4) defined organizational citizenship behavior as "voluntary individual behaviors that provide functional development of the organization, while not being part of the formal reward system" (Çınar Altıntaş, 2006: 82). Based on the definitions provided, there is no objective criterion, such as a standardized pattern of organizational citizenship behavior, or norms of law of organization; but it appears that depending on the demands of the organizaton it is the totality of attitudes that emerged with individual initiatives. Greenberg and Baron (2000: 373) narrowed down the broad framework of organizational citizenship behavior into three basic characteristics:

- The organization member's display activities and behaviors beyond expectations, even if those behaviors are not specified in job description,

- It is done voluntarily,

- It is carried out without any award expactation or fear of penalty.

The important factors that determine the formation and development of organizational citizenship behavior are: organizational commitment, individual's mental condition, personality traits, work and job satisfaction, organizational justice, organization's individual needs, leadership characteristics, seniority and hierarchical levels, organizational vision, organizational characteristics, and organizational integration (Karaman and Aylan, 2012: 41-44). Within the organization, organizational citizenship behaviors appear basically in the following two forms (Özdevecioğlu, 2003: 119, Basım ve Şeşen, 2006: 85):

- In the event that an organization member actively participates in the organization's activities and contributes to the organizational structure, works for the targets determined by the organization,

- Or the organization members remain passive by keeping away from all kinds of behaviors that might bring harm to the organizational structure. 
According to Şahin (2010: 32), organizational members will exhibit organizational citizenship behavior as a result of harmonizing organizational and employees' individual goals and objectives. By increasing the organizational performance of organizational citizenship behavior, the burden on the Resource Management functions is also reduced; Accordingly, organizational success is likely to increase (Yücel and Samanc1, 2009: 116).

By means of outcomes, Williams and Anderson (1991) classify organizational citizenship behaviors in two categories: towards organization and individual (Iplik et al., 2014: 112)

- Organizational Attitude toward Citizenship (OATC): Behaviors that arise from the interactions between individuals when benefits are provided to that individual and organization benefit from those interactions between individuals.

- Citizenship Behavior towards Organizations (CBTO): The totality of behaviors that arise as a result of actions that contributes to the organization while avoiding behaviors that may be harmful. They arise from the interaction between an individual and an organization.

\subsection{Organizational Citizenship Behavior's Dimensions}

Experts working on organizational citizenship behaviors have determined a set of dimensions for OCB. Van Dyne et al. (1994: 765-802) identified organizational citizenship behavior dimensions as "loyalty, obedience, and participation". Deckop, Mangel and Cirka (1999) point out that OCD is described in three dimensions as "helping behavior, gentleness, and conscientiousness" (Oguz, 2011: 381) while Farh, Earley and Lin (1997: explain it in five different dimensions by observing Chinese people's characteristics and conclude as, "identification with business and other colleagues, conscientiousness, interdependence of members and protection of organization's resources" .

Podsakoff et al. (2000: 516) has diminished the dimensions from 30 to 7 and cited them as "being helpful, sportsmanship, organizational loyalty, organizational obedience, individual initiative, civil virtue, and selfimprovement" . On the other hand, while Graham (1991: 249) sets three dimensions to OCB as "obedience, loyalty and political participation"; Williams and Anderson (1991) have set two: "responsible behaviors towards certain people" ("altruism and courtesy") and "behaviors that are wholly beneficial to the organizaton: integrity, gentility and civic virtue" (Koster and Sanders, 2005: 54). Organ (1988: 7-13) who coined the term of organizatonal citizenship behavior and introduced to the academic literature, has examined this concept in five dimensionss (Bolat et al., 2009: 218):

- Altruism: includes behaviors when the organization members assist each other without an expectation or obligation.

- Conscientiousness: This dimension, which is also defined as sense of duty, is a voluntary behavior. Individual works and improves himself towards the benefit, target and goals of the organization without taking into consideration concepts such as time, space or job expectations.

- Courtesy: Voluntary behaviors that includes an organization member' actions such as alerting other member's before a problem or event occurs and showing extra attention and effort not to bother or distract others from their work or tasks.

- Gentility: Organization members' acting positively, such as not complaining about other members and in case of a negativity, showing positive behavior when things are not going well. Podsakoff et al. (2000: 517) has emphasized the importance of self -sacrifice, leaving behind personal feelings during tough times, uselessness of complaints and pointed out that the only solution would be to display positive behavior.

- Civil Virtues: Voluntary behaviors by individuals who participate in business programs or self improvement activities organized by their own organizations or other organizations when it is not mandatory.

\section{Quantitative and Qualitative Research on Organization's Organizational Citizenship Behavior}

In the light of information obtained from the detailed literature survey on the topic, another important phase of the research, the field study, has been initiated. As posed by Danışman and Özgen (2003: 96) earlier, one of the important questions sought to be answered during the research was whether organizational citizenship behavior can be understood by qualitative methods such as interviewing or observation or by quantitative methods in which certain measurements are taken. While some researchers argue that topics such as organizational citizenship behavior cannot be measured quantitatively and that they should be examined with qualitative methods such as 
observation and interview, others argue that quantitative methods should be used in organizational citizenship behavior studies (İpek, 1999: 415). Both methods have been used in the present study.

\subsection{Organizational Citizenship Behavior Paradigm Analysis}

\subsubsection{Methodology in Organizational Citizenship Behavior Paradigm Analysis Study}

Through the qualitative study, organizational citizenship behavior's visible elements were analyzed by observation, examination of previous documents (business documents, news related to management), interviews with senior and current administrators using numerous interviewing methods based on Schein's Joint Exploration through Iterative Interviewing Method (Schein, 1985: 113). All of the paradigms in this section are based on the cultural paradigms of the businesses that Schein $(1984,1985,1992,1996,2004,2009)$ examined in his books and articles. Invisible but significant datas about organizational leadership were collected through pre- prepared questions that were asked to management leaders and employees through meetings and interviews in the light of Bodnar's (1992) studies about cultural paradigms about organizational citizenship. In the method presented in Figure 1 and in a reconciliatory manner, an open communication method at the meetings was conducted in a participatory way. Before the questionnaire was given, employees were brought together with the employers. In general, important events and situations have been put forward to find out the thoughts and attitudes about organizational citizenship behavior of participants in an interactive and collective manner. After checking several times, the consistency and correctness of the information obtained has been finalized by the additional comments of the management.

\section{Figure 1. Studying Methodology of Organizational Citizenship Behavior Paradigm}

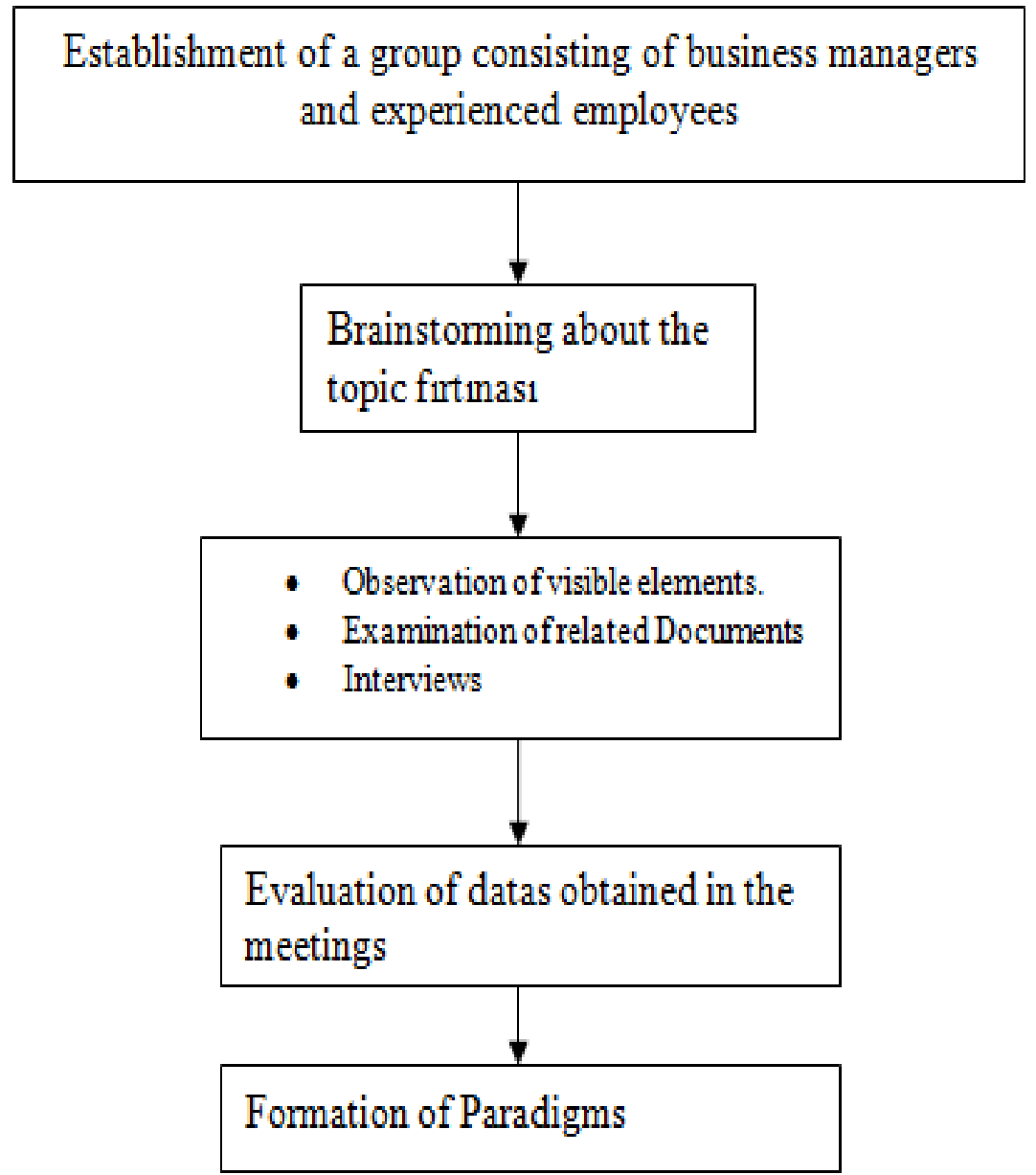

\subsubsection{Paradigm Analysis Study of Organizational Behavior of Organizational Citizenship}

In the Paradigm Analysis Study of Organizational Behavior of Organizational Citizenship, organizatonal culture has been determined as one of the most important factors influencing OCB and its dimensions. Şahin (2010: 32) 
argues that the employee in a strong cultural workplace is confident in his dealings, tasks, and knows his expected role or the boundaries between colleagues. In order to achieve organizational citizenship behavior at a desired level, it is necessary to create an organization culture with a fair atmosphere that values motivated members, provides a democratic atmosphere and encourages members, is open to communication where information exchange is swift and effective.

Moreover, organizational justice is a significant requirement in terms of exhibiting organizational citizenship behavior. As a matter of fact, during the interviews and meetings with employees, it has been observed that there is a strong emphasis on organizational justice asa token of displaying high level organizational citizenship behavior. It has also been observed that the subjects are positive in terms of their general approach to organizational citizenship behavior. Those with a higher level of education and more experience are respected more in the firm. Besides, it has been observed that employees emphasize the importance on compliance with the regulation of the organization.

Figure 2. Operator's Organizational Citizenship Behavior Paradigm Analysis of the Enterprise

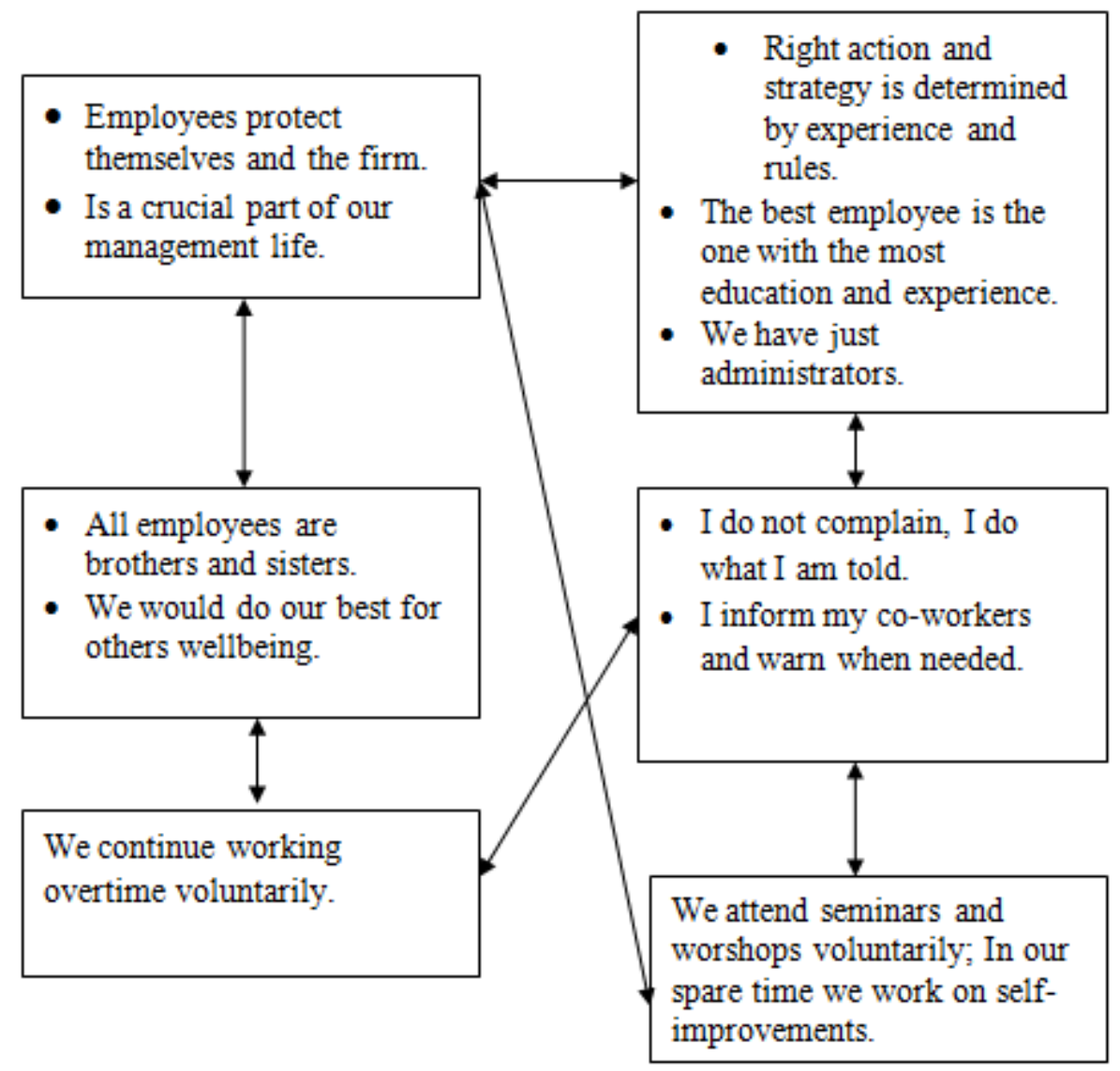

As indicated in the Figure 2, organizational citizenship behavior paradigm outcomes have been obtained in the light of information obtained from the interviews, observations, and conclusions from the meetings. As an alternative outcome, it has been observed that the employees are usually helpful to the youngsters or inexperienced employees. This is an indication of altruism, which is an indication of organizational citizenship behavior. In an atmosphere where team spirit is evident, employees are in a sacrifical mood. In order to achieve the objectives of the enterprise, it has been observed that employees working overtime contribute more to the objectives and goals of the organization. Working more than expected for the enterprise is an indication of conscientious behavior. In case of a crisis or a problem, employees try to find a solution instead of complaining or revolting and this is an indication of gentility. It's been observed that most employees, especially foremen state "I don't complain, I do what's necessary". On certain occasions, in case of information exchange, counseling or training activities, employees have exhibited gentlemanly manners during their interactions with each other and/or upper management. Sometimes employees join meetings voluntarily or when requested by their superiors. This is an indication of civil virtues. 


\subsection{Quantitative Study on Enterprise's Organizational Citizenship Behavior}

The quantitative research, which is implemented in terms of organizational citizenship behavior, is a field research. Primary sources are data obtained through a pre-prepared questionnaire and written questionnaire technique. For the research, a workshop in the textile sector in the central district of Adiyaman has been selected. This study was deemed to have a 95\% accuracy, with an estimated error level set for $5 \%$.

In the universe of 216 persons, 139 sampling has been calculated (The Survey System, 2015). 192 persons participated in the survey while attendance was calculated as \% 89. 186 persons have valid responses because of inccorrect or missing marking on organizational citizenship behavior survey. The study assumed that since the majority of employees participated, the survey reflected the relationship of organizational citizenship behavior accurately. The study further assumed that the factors and dimensions under discussion reflect the behavior of the organizational citizenship. It was also assumed that participants understood the questions in the questionnaire properly, they answered the questions realisticly, and their answers were honest and neutral. Since the majority of employees are female, the gender option has been removed from the questionnaire. Employees were assured that their answers to questionnaire will be used only for study's scope and nothing else and they are informed that name-surnames are not required. Participants involved in the survey were assumed to have objectively interpreted the questions and were encouraged to chose the most appropriate answer related to organizational citizenship behaviors and responses were given in a realistic and sincere manner. Obtained data's reliability and validity is limited to characteristics of the methodology used in collecting data. General limitations peculiar to social sicences such as time, space, and the nature of the human element is also applicable in this research. Findings obtained in the research are limited to the selected samples for a certain period of time.

\subsubsection{Formation of Data Collection Tools}

The survey begins with demographic questions. The OCB questionnaire was developed by Steel (2007: 198), which consists of 20 questions. The questionnaire was prepared by Podsakoff and Mackenzie and imroved by Çelik (2007, 198). Consisting of five dimensionss on a scale, each scale is made up of 4 questions. Survey questionnaires were presented to the approval of the experts on the subject and once the drawbacks were completed, the survey has been administered. The survey was administered either individually or collectively.

Table 1. Organizational Citizenship Behavior Scale and Sub-Dimensions Reliability Results

\begin{tabular}{|c|c|c|c|}
\hline & $\begin{array}{l}\text { Number } \\
\text { of Items }\end{array}$ & $\begin{array}{l}\text { Cronbach } \\
\text { Alpha Value }\end{array}$ & Reliability Results \\
\hline $\begin{array}{l}\text { Organizational } \\
\text { Behavior }\end{array}$ & 20 & 0,920 & Higly Reliable \\
\hline Altruism & 4 & 0,827 & Higly Reliable \\
\hline Conscientiousnessor Sense of Duty & 4 & 0,781 & Quite Reliable \\
\hline Courtesty & 4 & 0,752 & Quite Reliable \\
\hline Gentility & 4 & 0,673 & Quite Reliable \\
\hline Civil Virtues & 4 & 0,691 & Quite Reliable \\
\hline
\end{tabular}

The OCB quiestionnaire was graded according to Likkert's 5 point system and attendance levels have been determined as : (5) "Absolutely Agree", (4) "I Agree", (3) "Not sure", (2) "I Do not Agree" and finally (1) "I Absolutely Do not Agree". Iscan $(2002,184)$ states "with this scale, which was introduced in 1932 by Likert's as A Technique for Measuring Attitudes and was later developed by Spearman's Factor Theory, individuals responded to a series of proposals on the subject, and were expected to show a degree of agreement with the proposals". As shown in Table 1, as a result of the reliability analysis of organizational citizenship behavior, it was concluded that the organizational citizenship behavior scale consisting of 20 items was highly reliable with a Cronbach alpha value of 0.920 .

\subsubsection{Research Findings}

$82.2 \%$ of the respondents are between the ages of $18-44$, which indicates that the employees of the business are mostly made up of young people. 
Table 2. Distribution of Employees by Age Groups

\begin{tabular}{|lll|}
\hline Age Group & Number of People & \multicolumn{1}{c|}{} \\
18-24 Ages & 16 & 8,6 \\
25-34 Ages & 74 & 39,8 \\
35-44 Ages & 61 & 32,8 \\
45 years or more & 35 & 18,8 \\
Total & $\mathbf{1 8 6}$ & $\mathbf{1 0 0}$ \\
\hline
\end{tabular}

Instead of a job that fits their status of education, employees work according to their job description, which is based on fault- free and efficient production system. The majority of the employees are graduates of primary education (primary and secondary school).

Table 3. Distribution of Employees by Educational Status

\begin{tabular}{|lll|}
\hline Educational Status & Number of People & $\mathbf{\%}$ \\
Primary School & 126 & 67,7 \\
High School/ College & 60 & 32,3 \\
Total & $\mathbf{1 8 6}$ & $\mathbf{1 0 0}$ \\
\hline
\end{tabular}

The business is in need of qualified personnel: beginners work under the care and supervision of experienced workers for a period of 6 months to one year according to their job description. The total number of employees with 11 years or over experience constitutes $30 \%$ of the total number of employees.

Table 4. Distribution of Employees' Experiences in the Current Organization

\begin{tabular}{|lll|}
\hline Years of Experience & Number of Persons & \% \\
1-5 Years & 51 & 27,4 \\
6-10 Years & 79 & 42,5 \\
11 Years or more & 56 & 30,1 \\
Total & $\mathbf{1 8 6}$ & $\mathbf{1 0 0}$ \\
\hline
\end{tabular}

As shown in Table 5, while the average of organizational citizenship behavior scale of the participants in the survey was 4.17, the average of courtesy subscale was 4,13; conscience or sense of duty sub-dimensions average was 4,20; the average of the civil virtues sub-dimension was 4,17, the average of the altruism sub- dimensions was 4,13 , and finally the average of the gentilitysub-dimensions appeared as 4,05. According to the results of this study, the organizational citizenship behavior and the organizational citizenship behavior sub- dimensions are at a high level. In other words, these ratios indicate that employees are at a high level of possessing the attributes of organizational citizenship behavior and its dimensions.

Table 5. OCB Scale and Its Dimensions’ Average and Standard Deviation Evaluations

\begin{tabular}{|lcc|}
\hline \multicolumn{3}{|c|}{ Average Standard Deviation } \\
\hline Organizational Citizenship Behavior 4,17 & 0,585 \\
Altruism & 4,13 & 0,713 \\
Conscientiousness & 4,20 & 0,593 \\
Courtesy & 4,30 & 0,667 \\
Gentility & 4,05 & 0,618 \\
Civil Virtues & 4,17 & 0,641 \\
\hline
\end{tabular}

In terms of organizational citizenship behaviors and its dimensions, employees have been examined whether there are any differences among employees who have different education status, age and experience. 
Table 6. Test whether there are differences among employees who have different education status, age, and experience (T Test)

\begin{tabular}{|c|c|c|c|c|c|c|c|c|}
\hline Scale & & Education Status & $\begin{array}{l}\text { Number } \\
\text { Persons }\end{array}$ & of & $\begin{array}{l}\text { Averag } \\
\text { e }\end{array}$ & $\begin{array}{l}\text { Standard } \\
\text { Deviation }\end{array}$ & $\mathbf{T}$ & $\mathbf{P}$ \\
\hline \multirow[b]{2}{*}{$\begin{array}{l}\text { Organizational } \\
\text { Behavior }\end{array}$} & \multirow{2}{*}{ Citizenship } & Primary School $^{\top}$ & 126 & & 4,18 & 0,655 & \multirow[b]{2}{*}{0,212} & \multirow[b]{2}{*}{$\begin{array}{l}0,83 \\
2\end{array}$} \\
\hline & & $\begin{array}{l}\text { High School } \\
\text { College }\end{array}$ & / 60 & & 4,16 & 0,401 & & \\
\hline \multirow[b]{2}{*}{ Altruism } & & Primary School & 126 & & 4,16 & 0,777 & \multirow[b]{2}{*}{0,667} & \multirow[b]{2}{*}{$\begin{array}{l}0,50 \\
5\end{array}$} \\
\hline & & $\begin{array}{l}\text { High School } \\
\text { College }\end{array}$ & / 60 & & 4,08 & 0,559 & & \\
\hline \multirow[b]{2}{*}{ Conscientiousness } & & Primary School & 126 & & 4,23 & 0,638 & \multirow[b]{2}{*}{0,959} & \multirow[b]{2}{*}{$\begin{array}{l}0,33 \\
9\end{array}$} \\
\hline & & $\begin{array}{l}\text { High School } \\
\text { College }\end{array}$ & / 60 & & 4,14 & 0,483 & & \\
\hline \multirow[b]{2}{*}{ Courtesy } & & Primary School & 126 & & 4,29 & 0,745 & \multirow{2}{*}{$\begin{array}{l}- \\
0,439\end{array}$} & \multirow{2}{*}{$\begin{array}{l}0,66 \\
1\end{array}$} \\
\hline & & $\begin{array}{l}\text { High School } \\
\text { College }\end{array}$ & / 60 & & 4,33 & 0,466 & & \\
\hline \multirow[b]{2}{*}{ Gentility } & & Primary School & 126 & & 4,07 & 0,676 & \multirow[b]{2}{*}{0,770} & \multirow{2}{*}{$\begin{array}{l}0,44 \\
3\end{array}$} \\
\hline & & $\begin{array}{l}\text { High School } \\
\text { College }\end{array}$ & ${ }^{\prime} 60$ & & 4,00 & 0,476 & & \\
\hline \multirow{2}{*}{\multicolumn{2}{|c|}{ Civil Virtues }} & Primary School & 126 & & 4,13 & 0,718 & & \\
\hline & & $\begin{array}{l}\text { High School } \\
\text { College }\end{array}$ & / 60 & & 4,26 & 0,426 & 1,368 & 3 \\
\hline
\end{tabular}

For the Organizational Citizenship Behavior Scale, the primary school graduate level is 4,18 while the high school / college graduate level is 4,16. As a result of the independent sample t-test, there was no significant difference in terms of Organizational Citizenship Behavior between primary school and high school / college graduates (t: 0,$212 ; p>0,05)$. In terms of the altruism sub-dimensions, primary school graduate level is 4,16 while high school / college graduate level is 4,08. As a result of the independent sample t-test, there was no significant difference between primary school and high school / college graduates in terms of the altruism gentility subdimension (t: 0,$667 ; \mathrm{p}>0,05)$.

In terms of conscience subscale, primary school graduate level is 4.23 while high school / college graduate level is 4,14 . As a result of the independent sample t-test, no significant difference was found between primary school and high school / college graduates in terms of conscience sub-dimension (t: 0,959, $\mathrm{p}>0,05)$. In terms of courtesy sub-dimension, primary school graduate level is 4.29 while high school / college graduate level is 4.33 . As a result of the independent sample t-test, there is no significant difference in courtesy sub-dimension between elementary school and high school / college graduates $(\mathrm{t}:-0,439 ; \mathrm{p}>0,05)$. In terms of gentility sub-dimension, primary school graduate level is 4,07 while high school / college graduate level is 4,00. As a result of the independent sample t-test, there was no significant difference between gentility of primary and high school / college in terms of gentility sub-dimension (t: 0,$770 ; p>0,05)$. In terms of civil virtue sub-dimension, the level of primary education graduate is 4,13 while the level of high school / college graduate is 4,26 . As a result of the independent sample t-test, there is no significant difference between the primary and high school / college graduates in terms of the civil virtue sub-dimension(t: $-1,368 ; p>0,05)$. In terms of civil virtue sub-dimension, the level of primary education graduate is 4,13 while the level of high school / college graduate is 4,26. As a result of the independent sample t-test, there is no significant difference between the primary and high school / college graduates in terms of the civil virtue sub-dimension (t: $-1,368 ; p>0,05)$.

${ }^{1}$ Primary school has been used as collective term for both primary and secondary school. 
Table 7. Whether there is difference Between Workers with Different Work Experience in Terms of Organizational Citizenship Behavior and Its Dimensions (ANOVA)

\begin{tabular}{|c|c|c|c|c|c|c|}
\hline \multirow{4}{*}{\begin{tabular}{|l} 
Scale \\
Organizational \\
Citizenship Behavior
\end{tabular}} & \multirow{2}{*}{$\begin{array}{l}\text { Work Experience } \\
1-5 \text { Years }\end{array}$} & \multicolumn{2}{|c|}{ Average } & \multirow{2}{*}{$\begin{array}{l}\begin{array}{l}\text { Standard } \\
\text { Deviation }\end{array} \\
0,60961\end{array}$} & \multirow[t]{2}{*}{$\mathbf{F}$} & \multirow[t]{2}{*}{$\mathbf{P}$} \\
\hline & & 51 & 4,1716 & & & \\
\hline & 6-10 Years & 79 & 4,1342 & 0,83126 & 0,074 & 0,929 \\
\hline & 11 Years or more & 56 & 4,0884 & 0,62384 & & \\
\hline \multirow{3}{*}{ Altruism } & $1-5$ Years & 51 & 4,1765 & 0,48149 & & \\
\hline & 6-10 Years & 79 & 4,2367 & 0,72839 & 0,182 & 0,834 \\
\hline & 11 Years or more & 56 & 4,1821 & 0,46519 & & \\
\hline \multirow{3}{*}{ Conscientiousness } & $1-5$ Years & 51 & 4,2471 & 0,62397 & & \\
\hline & $6-10$ Years & 79 & 4,3392 & 0,74204 & 0,211 & 0,810 \\
\hline & 11 Years or more & 56 & 4,3 & 0,59818 & & \\
\hline \multirow{3}{*}{ Courtesy } & $1-5$ Years & 51 & 4,1078 & 0,51763 & & \\
\hline & 6-10 Years & 79 & 4,0595 & 0,70484 & 0,294 & 0,746 \\
\hline & 11 Years or more & 56 & 3,9804 & 0,57316 & & \\
\hline \multirow{3}{*}{ Gentility } & $1-5$ Years & 51 & 4,1275 & 0,59433 & & \\
\hline & $6-10$ Years & 79 & 4,1886 & 0,7473 & 0,585 & 0,558 \\
\hline & 11 Years or more & 56 & 4,1839 & 0,51514 & & \\
\hline \multirow{3}{*}{ Civil Virtues } & $1-5$ Years & 51 & 4,1667 & 0,49423 & & \\
\hline & $6-10$ Years & 79 & 4,1873 & 0,69326 & 0,158 & 0,854 \\
\hline & 11 Years or more & 56 & 4,1482 & 0,4947 & & \\
\hline
\end{tabular}

For the Organizational Citizenship Behavior scale, employees with the level of 1-5 years of experience is 4.17, while employees with the experience of the level of 6-10 years is 4,13; the level of employees with experience of 11 years is 4.09. As a result of the one way analysis of variance, there was no significant difference between the employees with different work experience in terms of IGTS Citizenship Behavior scale (F: 0,074; p> 0,05)

While the level of employees with an experience of 1-5 years altruism sub-dimension is 4.18 , the level of employees with 6-10 years of experience is 4,24; employees with an experience of 11 years level is 4.18. As a result of the one way analysis of variance, there was no significant difference in the subscale of the altruism among the workers with different work experience (F: 0,182; $>>0,05)$.

The subscale of conscience is 4,25 for employees with an experience of 1-5 years and 4,34 for 6-10 years; for employees with an experience of 11 years the level of is 4.30. As a result of the one-way analysis of variance, there was no significant difference in conscience subscale among the workers with different work experience (F: $0,211 ; \mathrm{p}>0,05)$.

For the courtesy sub-dimension, the level of 1-5 years employees is 4.11, while the level of 6-10 years employees is 4.06; for employees with experience of 11 years, the level is 3.98. As a result of the one-way analysis of variance, there is no significant difference in courtesy subscale among workers with different work experience (F: 0,294; $p>0,05)$.

For the gentility subscale for employees with 1-5 years experience the level is 4,13 and 4,19 for 6-10 years; for employees with experience of 11 years the level of employees is 4.18. As a result of the one way analysis of variance, there is no significant difference in gentility subscale among the workers with different work experience (F: 0,$585 ; \mathrm{p}>0,05)$.

The level of 1-5 year employees for Civil Virtue sub-dimension is 4.18, while the level of employees with the experience of 6-10 years is 4,19; for employees with experience of 11 years the level is 4,15. As a result of the one-way analysis of variance, there is no significant difference in the Civic Virtue sub-dimension among the workers with different work experience (F: 0,158; $p>0,05)$. 
Table 8. Whether there is a difference Between Employees of Different Age Groups in Terms of Organizational Citizenship Behavior and Its Dimensions (ANOVA)

\begin{tabular}{|c|c|c|c|c|c|c|}
\hline Scale & Age Group & $\mathbf{N}$ & Average & Standard Deviation & $\mathbf{F}$ & $\mathbf{P}$ \\
\hline \multirow{4}{*}{$\begin{array}{l}\text { Organizational } \\
\text { Citizenship } \\
\text { Behavior }\end{array}$} & 18-24 Years of Age & 16 & 3,9562 & 0,33059 & \multirow{4}{*}{1,662} & \multirow{4}{*}{0,177} \\
\hline & 25-34 Years of Age & 74 & 4,2581 & 0,48343 & & \\
\hline & 35-44 Years of Age & 61 & 4,0967 & 0,73507 & & \\
\hline & 45 Years or Above & 35 & 4,2086 & 0,55326 & & \\
\hline \multirow{4}{*}{ Altruism } & 18-24 Years of Age & 16 & 3,7375 & 0,55961 & \multirow{4}{*}{3,149} & \multirow{4}{*}{0,026} \\
\hline & 25-34 Years of Age & 74 & 4,2588 & 0,60417 & & \\
\hline & 35-44 Years of Age & 61 & 4,0262 & 0,87748 & & \\
\hline & 45 Years or Above & 35 & 4,2214 & 0,59127 & & \\
\hline \multirow{4}{*}{ Conscientiousness } & 18-24 Years of Age & 16 & 4,1 & 0,21292 & \multirow{4}{*}{0,530} & \multirow{4}{*}{0,662} \\
\hline & 25-34 Years of Age & 74 & 4,2338 & 0,53744 & & \\
\hline & 35-44 Years of Age & 61 & 4,1541 & 0,74152 & & \\
\hline & 45 Years or Above & 35 & 4,2743 & 0,53432 & & \\
\hline \multirow{4}{*}{ Courtesy } & 18-24 Years of Age & 16 & 4,1 & 0,47046 & \multirow{4}{*}{1,499} & \multirow{4}{*}{0,216} \\
\hline & 25-34 Years of Age & 74 & 4,4135 & 0,56649 & & \\
\hline & 35-44 Years of Age & 61 & 4,2197 & 0,8483 & & \\
\hline & 45 Years of Age & 35 & 4,3029 & 0,55439 & & \\
\hline \multirow{4}{*}{ Gentility } & 18-24 Years of Age & 16 & 3,9313 & 0,42539 & \multirow{4}{*}{0,909} & \multirow{4}{*}{0,438} \\
\hline & 25-34 Years of Age & 74 & 4,1378 & 0,51914 & & \\
\hline & 35-44 Years of Age & 61 & 4,0066 & 0,73686 & & \\
\hline & 45 Years or Above & 35 & 3,9886 & 0,65654 & & \\
\hline \multirow{4}{*}{ Civil Virtues } & 18-24 Years of Age & 16 & 3,9125 & 0,25265 & \multirow{4}{*}{1,694} & \multirow{4}{*}{0,170} \\
\hline & 25-34 Years of Age & 74 & 4,2568 & 0,61668 & & \\
\hline & 35-44 Years of Age & 61 & 4,0984 & 0,73246 & & \\
\hline & 45 Years or Above & 35 & 4,2314 & 0,61776 & & \\
\hline
\end{tabular}

For the organizational citizenship behavior scale, the level between the ages of 18-24 is 3.96, while the level between the ages of 25-34 is 4.26; Level of people between 35 and 44 years is 4,10; The level of those aged 45 and over is 4,21 . As a result of the one way analysis of variance, there was no significant difference between the groups of different age groups in terms of NGS citizenship behavior scale (F: 1,662, p <0,05).

For the Altruism sub- dimension, while the level for the ages of 18-24 is 3.74, the level of ages of 25-34 is 4,26; Level of people between ages of 35-44 years is 4.03; The level of those aged 45 and over is 4,22. As a result of the one-way analysis of variance, there is a significant difference in behaviors of different age groups (F: 3,149, p $<0,05)$. As one gets older, there is a tendency towards exhibiting altruism sub- dimension.

As one gets older, there is a growing tendency to show altruism behavior. It can be inferred that experiences are transferred to new employees and more sacrifices are made towards organizations's goals and objectives when compared to younger employees.

For the subscale of conscience, for the ages of 18-24 the level is 4.1, while the level for ages $25-34$ is 4.23 ; The level of those between the ages of 35 and 44 is 4,15; The level of those aged 45 and over is 4.27. As a result of the one way analysis of variance, there was no significant difference in conscientious behavior among different age groups (F: 0,530, p <0,05).

For the courtesy sub-dimension, for the ages of 18-24 the level is 4.1, while the level for the ages $25-34$ is 4 , 14; for the level of people between 35-44 years 4.01; The level of those aged 45 and over is 4.30. As a result of the one-way analysis of variance, there was no significant difference in the kindness behaviors among the different age groups (F: 1,499, p <0,05). 
For the gentility subdimension, the level for the ages between 18-24 is 3.93, while the level for the ages between the ages 25-34 is 4.26; for the people between 35-44 years the level is 4.03; The level of those aged 45 and over is 3.99. As a result of the one way analysis of variance, there was no significant difference in gentility behavior among different age groups (F: 0,909, $\mathrm{p}<0,05)$.

For the civil virtue subscale, the level for the ages between 18-24 is 3.91, while the level for the ages between 2534 is 4.26; Level of people between 35 and 44 years is 4,10; The level of those aged 45 and over is 4.23. As a result of the one-way analysis of variance, there is no significant difference in the civic virtue behaviors among different age groups (F: 1,694, $\mathrm{p}<0,05)$.

\section{Results and Evaluation}

Organizational citizenship behavior, which is examined by many disciplines, is an important field of study for organizations, especially businesses. It is necessary to examine organizational citizenship behaviors in order to understand the spirit, the behavior, and mindset of employees that governs the businesses. The internal structure, organizational activity, organizational network of relationships, organizational goals and objectives, the technology used, organizational culture, or other influential factors determine the formation of organizational citizenship behavior. Employees who have internalized organizational values and culture, or voluntary behaviors contribute a lot both to the organization and employees.

Organization culture is an important factor affecting OCB and its dimensions. According to Berberoğlu (1990: 155), since organizations' aim and needs varry, organizations culture include differences accordingly. It would not be wrong to claim that difference between organizational cultures would influence employee's behavior and attitudes. In other words, the difference in organizational culture will affect the exhibition of OCB positively or adversely. Members are in a way representative of their organizations as their behavior and attitudes give clues about organizational citizenship behavior.

In the present research, it has been aimed to contribute to the literature by using both qualitative and quantitative research methods in relation to organizational citizenship behaviors and its dimensions. As a result of the analysis, it has been determined that the level of exhibiting OCB and its dimensions is high. The research also determined that factors such as the level of education, age range and work experience do not cause any differentiation in organizational citizenship and its dimensions.

It is hoped that the results of OCB analyzed by different methodology will contribute to the literature in terms of future OCD studies and will further provide important benefits to the field. For the limitation aspect of the study, empirical data is limited to a textile company and to a certain a region. The application has been limited to a textile company within Adryaman district and in order to make a generalization a wider scope of sampling is necessary and inevitable.

Additionally, if a research is done in different business sectors and different regions, researchers will obtain various results. It is possible to make significant contribution to the study of organizational citizenship behavior in academic sense if the concept is analyzed in different districts, increasing the number of various samplings or even different sectors are included. The limitation aspect could be diluted with different questions and methods. Besides, the mentioned applications will enrich the academic literature undoubtedly if a more general and broad research is conducted in terms of organizational commitment, organizational culture, organizational support, and job satisfaction and motivation factors.

\section{References}

Arslantaş, C. C. ve Pekdemir, I. (2007), “Dönüşümcü Liderlik, Örgütsel Vatandaşlık Davranışı ve Örgütsel Adalet Arasındaki İlişkileri Belirlemeye Yönelik Görgül Bir Araştırma”, Anadolu Üniversitesi Sosyal Bilimler Dergisi, 7(1): 261-286.

Aslan, Ş.(2008), “Örgütsel Vatandaşlık Davranış1 ile Örgütsel Bağlılık ve Mesleğe Bağlılık Arasındaki İliskilerin Araştırılması”, Celal Bayar Üniversitesi İktisadi ve İdari Bilimler, Yönetim ve Ekonomi Dergisi, 15(2): 163-178.

Basım H. N. ve Şeşen H.(2006), “Örgütsel Vatandaşlık Davranışı Ölçeği Uyarlarna ve Karşılaştırma çalışması”, Ankara Üniversitesi SBF Dergisi, 61(4): 83-101. 
Berberoğlu, G.N. (1990),“ Örgüt Kültürü ve Yönetsel Etkinliğe Katkısı”, Anadolu Üniversitesi İktisadi ve İdari Bilimler Fakültesi Dergisi, 8 (1-2): 153-161

Bodnar, B.A.B. (1992), A Study of the Basic Cultural Assumptions of a School . (Unpublished PhD Dissertation). Saskatoon: College of Graduate Studies and Reserach (CGSR). University of Saskatchewan.

Bolat O. İ., Bolat T. ve Seymen Aytemiz O. (2009), "Güçlendirici Lider Davranısları ve Örgütsel Vatandaslık Davranısı Arasındaki İlişkin Sosyal Mübadele Kuramından Hareketle İncelenmesi”, Balıkesir Üniversitesi Sosyal Bilimler Enstitüsü Dergisi, 12(21): 215-239.

Brief, A.P. ve Motowidlo, S.J. (1986),"Prosocial Organizational Behaviors", Academy of Management Review, 11(4): 710-725.

Çelik, M. (2007), Örgüt Kültürü ve Örgütsel Vatandaşlık Davranışı - Bir Uygulama. (Yayınlanmamış Doktora Tezi).Erzurum: Atatürk Üniversitesi Sosyal Bilimler Enstitüsü.

Çınar Altıntaş, F.(2006), "Hizmet Çalışanları Olarak Hemşirelerin Örgütsel Vatandaşlık Davranışı Boyutlarını Belirlemeye Yönelik Bir Analiz ”, Yönetim Bilimleri Dergisi, (4: 2): 81-90.

Danaeefard H., Balutbazeh A.E. ve Kashi K.H.A (2010), “Good Soldiers' Perceptions Of Organizational Politics Understanding The Relation Between Organizational Citizenship Behaviors And Perceptions Of Organizational Politics: Evidence From Iran", European Journal of Economics, Finance and Administrative Sciences, 18: 146-162.

Danışman, A. ve Özgen, H. (2003), “Örgüt Kültürü Çalışmalarında Yöntem Tartışması: Niteliksel-Niceliksel Yöntem İkileminde Niceliksel Ölçümler ve Bir Ölçek Önerisi”, Yönetim Araşstırmaları Dergisi, 3(2): 91124.

Farh J. P., Earley C. and Lin S.(1997), "Impetus For Action: A Cultural Analysis Of Justice And Organizational Citizenship Behavior In Chinese Society", Administrative Science Quarterly, 42(3): 421-444.

Finkelstein, M. A. and Penner, L. A. (2004), "Predicting Organizational Citizenship Behavior: Integrating the Functional and Role Identity Approaches.” Social Behavior and Personality, 32: 383-398.

George, J. M. (1991),“ State Or Trait: Effects Of Positive Mood On Prosocial Behaviors At Work ”, Journal of Applied Psychology, 76(2): 299-307.

George, J. M. and Brief, A. P. (1992),“ Feeling Good-Doing Good: A Conceptual Analysis Of The Mood At Work-Organizational Spontaneity Relationship”,Psychological Bulletin, 112: 310-329.

George J.M. and Jones, G.R. (1997),“ Organizational Spontaneity In Context”, Human Performance, 10(2): 153170.

Goodman, S. A. and Svyantek, D. J. (1999),“Person-Organization Fit And Contextual Performance: Do Shared Values Matter?", Journal of Vocational Behavior, 55: 254-275.

Graham, J. (1991),“An Essay On Organizational Citizenship Behavior”, Employee Responsibilities and Rights Journal, 4(4): 249-270.

Greenberg, J. and Baron, R.A. (2000). Behavior In Organizations (Seventh Edition). Upper Saddle River: Prentice Hall.

Gürbüz, S. (2006), “Örgütsel Vatandaşlık Davranışı ile Duygusal Bağl1lık Arasındaki İlişkilerin Belirlenmesine Yönelik Bir Araştırma". Ekonomik ve Sosyal Araştırmalar Dergisi, 3(1) , 48-75.

İpek, C. (1999), “Resmi liseler ile özel liselerde örgütsel kültür ve öğretmen-öğrenci ilişkisi”,Eğitim Yönetimi Dergisi, 5(19): 411-442.

İplik E., İplik F.N. ve Efeoğlu İ.E.(2014), “Çalışanların Örgütsel Destek Algılarının Örgütsel Vatandaşlık Davranışı Üzerindeki Etkisinde Örgütsel Özdeşleşmenin Rolü”, International Journal of Economic and Administrative Studies, 6(12): 109-122

İşcan, Ö. F. (2002). Küresel Işsletmecilikte Dönüştürücü Liderlik Anlayış-Büyük Ölçekli İşletmelerde Bir Uygulama. (Yayınlanmamış Doktora Tezi). Erzurum: Atatürk Üniversitesi Sosyal Bilimler Enstitüsü.

Karaman, A. ve Aylan, S.(2012), “Örgütsel Vatandaşl1k”, Kahramanmaraş Sütçü İmam Üniversitesi İktisadi ve İdari Bilimler Fakültesi Dergisi, 2(1): 35-48.

Katz, D. and R.L. Kahn (1978). The Social Psychology of Organizations. NewYork: John Wiley \& Sons. 
Koster, F ve Sanders, K.(2005). "Organizational Relations Or Reciprocal Relations? An Empirical Comparison”. Koster, F. (Ed.),For The Time Being: Accounting For Inconclusive Findings ConcerningThe Effects Of Temporary Employment Relationships On Solidary Behavior Of Employees (pp.51-76). Veenendaal: Universal Press.

Oğuz, E. (2011), “Öğretmenlerin Örgütsel Vatandaşlık Davranışları ile Yöneticilerin Liderlik Stilleri Arasındaki İlişki”, Kuram ve Uygulamada Ĕgitim Yönetimi Dergisi, 17(3), 377-403

Organ, D. W. (1988). Organizational Citizenship Behavior: The Good Soldier Syndrome. Lexington: Lexington Books.

Organ, D. W. and Konovsky, M. A. (1989) "Cognitive versus affective determinants of organizational citizenship behavior", Journal of Applied Psychology, 74: 157-164

Özdevecioğlu, M. (2003), “Örgütsel Vatandaşlık Davranışı ile Üniversite Öğrencilerinin Bazı Demografik Özellikleri ve Akademik Başarıları Arasındaki İlişkilerin Belirlenmesine Yönelik Bir Araştırma”, Erciyes Üniversitesi İktisadi ve İdari Bilimler Fakültesi Dergisi, 20, 117 - 135.

Podsakoff P.M., MacKenzie S.B., Paine J.B. and Bachrach D.G. (2000), “Organizational Citizenship Behaviors: A Critical Review Of The Theoretical And Empirical Literaturen And Suggestions For Future Research", Journal of Management, 26(3), 513-563.

Schein, E. H. (1985).Organizational Culture And Leadership. San Francisco: Jossey Bass Publishers.

Schein, E. H. (1990). "Organizational Culture”. American Psychologist, 45(2), 109-119.

Schein, E. H. (1992).Organizational Culture And Leadership (Secon Edition). San Francisco: Jossey Bass Publishers.

Schein, E. H. (1996).“Culture: The Missing Concept In Organization Studies”. Administrative Science Quarterly, 41(2), 229-240.

Schein, E. H. (1996)."Three Cultures Of Management: The Key To Organizational Learning”. Sloan Management Review, 38(1), 9-20.

Schein, E.H. (1996).“Culture: The Missing Concept In Organization Studies”. Administrative Science Quarterly, 41, 229-241.

Schein, E.H. (2002).“ Örgütsel Kültür”. (Çev. Atilla Akbaba). Dokuz Eylül Üniversitesi Sosyal Bilimler Enstitüsü Dergisi, 4(1), 1-32

Schein, E.H. (2004).Organizational Culture And Leadership (Third Edition). San Francisco: Jossey-Bass Publishers.

Schein, E.H. (2009).The Corporate Culture: Survival Guide. San Francisco: Jossey-Bass Publishers.

Sezgin, F. (2005),“ Örgütsel Vatandaşlık Davranışları: Kavramsal Bir Çözümleme ve Okul Açısından Bazı Çıkarımlar”, Gazi Üniversitesi Gazi Ĕ̌itim Fakültesi Dergisi, 25(1): 317-339.

Şahin, A.(2010), “Örgüt Kültürü-Yönetim İlişskisi ve Yönetsel Etkinlik”, Maliye Dergisi,159, 21-35.

The Survey System(2015).Sample Size Calculator. Erişim Tarihi: 12 Ocak 2015, http://www.surveysystem.com/sscalc.htm,

Van Dyne L., Cummings L.L. and McLean Parks J. (1995), "Extra-Role Behaviors: In Pursuit of Construct and Definitional Clarity", In Cummings, L. L. \& Staw, B. M. (Eds.), Research in Organizational Behavior (pp.215-284).Greenwich, CT: JAI Press.

Williams, L.J. and Anderson, S.E. (1991),"Job Satisfaction And Organizational Commitment As Predictors Of Organizational Citizenship And In-role Behaviors", Journal of Management, 17(3), 601-617.

Yücel, C. ve Samancı G.(2009), “Örgütsel Güven ve Örgütsel Vatandaşl1k Davranışı”, Fırat Üniversitesi Sosyal Bilimler Dergisi, 19(1), 113-132. 